\title{
Destination managament in Hungarian tourism
}

\author{
Lóránt Dávid - Anett Tözsér \\ Department of Tourism and Regional Development \\ Károly Róbert College
}

\begin{abstract}
The principle of the regional concentration - as one of the important means of regional competitiveness - and the cooperations being organised more consciously have big parts in the development and operation of the tourist destination management. The principle of complexity is emphasised differently that means, on the one hand, the more effective use of the connection possibilities of tourism to other branches, on the other hand, it takes for granted the development of the background infrastructure supporting tourism more intensively beside the development of the tourist infrastructure. The basic principle of the competitive developments are the sustainable developments and the innovative approach. Tourist destination can be identified with the tourist supply (product) from the elements of the tourist system: the tourist supply and the tourist destination are consisting just of the same elements. The difference is that the tourist product can be only one product and destination can be characterised as a complex pile of attractions and services being in connection with each other. The cooperation of the characters of destination are organised by the tourist value chain of which elements are the experiences in connection with the formation of the image, preparation of travel, travel, destination, return from the point of view of the tourist and the service providers of destination. Services of different level provided by the suppliers can influence the opinion and experience of the tourist in connection with destination negatively. The independent destination management system with suitable competence and specialists, running a coordinating activity can make a connection between the tourist and the receiving area.
\end{abstract}

Key words: destination, destination management, tourist value chain

\section{Introduction}

The globalisation of tourism, the fast and constant change of the tourist market, the increasing competition between tourist areas require faster and more flexible changes, reactions on behalf of the macro- and microenvironment of tourism. That is the reason why the current management and operation process of tourism need to be changed and renewed. The present structure of tourism management and operation is being revaluated and replaced by the modern tourism management and operation system, the regional and organizational system of destination management.

Destination management means the current practice of complex and integrated planning and operation of tourism with the difference that ,the principle of regional concentration"as one of the important means of regional competitiveness -, and the regional cooperations operating more consciously and reasonably are getting a more significant role in reconsidering the system of tourism in a more modern form.

The principle of complexity is emphasised differently, which means on the one hand, the more effective use of the connection possibilities of tourism to other branches, on the other hand, the more intensive development of the background infrastructure supporting tourism beside the tourist infra- and superstructure. The basic principles of the competitive developments are the sustainability and the innovative approach.

Present publication focuses on the development of the above complex system, it mentions the characteristics of tourism destination and those of tourist destination management, their places in the system of tourism and it also deals with the operation of the tourist value chain. At the same time the article explains the connection between tourist product and tourist destination as well as the behaviour of destinations, which influence the duties of destination management organisations.

\section{Methods and Materials}

The publication reviews the characteristics of the destination and the destination management. For analysing the principles of the tourism destination management, the searchers used the wider literature of the tourism destination management. On the bases of the studies, we offered an opinion about the necessity and the set-up of the destination management system, specially in Hungary.

\section{Results and discussion}

\subsection{Necessity of the development of tourism destination management}

The destinations - as organizational systems based on regional concentration and cooperation - have to take into consideration the global economic processes. The basic 
principle of these processes is that the durable industrial and business competitive advantages appear to be more and more concentrated geographically. The participants of the competition are not individuals, but the basic units of the market, companies, enterprises and regional institutions. The establishment and operation of these systems are helped by the EU orders as well as financial support.

The regional concentration principle plays a determinant role in the effective operation of the destination, because it generates competitive advantages. The tourist target areas are worth settling to a regional concentration being significant from the point of view of tourism, based on definitive basic principles, so that the economic potential of the region can be increased.

Determinant factors of the tourist competitiveness of each region are the development and operation of the management system with the effective, suitable competences and calculable financing and organisational background.

Modern tourism management and operation, that is the revaluation of the current traditions, are necessary for the development of an effective management system organised on the basis of the regional concentration principle. The integrated planning, management and operation of tourism are needed on all levels of tourism. Development of the system is taking for granted such kind of regional and organisational planning basic principles as the:

- Revaluation of cooperation, development of consciousness in the cooperation, development, planning, organisation, operation of the forms of cooperation;

- More close cooperation with other regions, branches in the processes of planning and development originating from the multiplier effect of tourism;

- More complex approaches in the development of the service system of tourism: beside the development of the tourist infra- and superstructure the development of the background infrastructures, the supporting factors have to be emphasized too;

- The use of innovative, modern, up to date technologies in the processes of development.

\subsection{Concept of the tourist destination, its characteristics}

The characteristics of the destination, its concept, can be revealed in forming factors and of the „,behaviour”, nature of destination.

In the conceptual estimation of destination different standing-points can be followed. In the whole, destination (Dr. Roger Carter - Dr. Mike Fabricius, 2007) is a physical location where the tourist is spending at least one night. It is containing tourist attractions, products, relating services that are necessary to meet the stay of a tourist on the place at least for one day.

Destination has physical and administrative limits, which are determining its management, and has an image and perception. It includes a lot of elements being concerned, it is capable for constructing a network, a cooperation and to become a bigger destination; the determination of destination is made from the point of view of the tourist.

To create a tourist destination the location, or region has to have the factors that determine the tourist destination. These factors are determinants in the bordering, determination of the core area destination; their development is essential by the increase of the competitiveness of the specific destinations. According to Buhalis (2000), the determinants of the destination are as follows:

- Tourist attractions, e.g. natural factors, man-made factors, heritage, special events, etc.;

- Approachability, e.g. the entire traffic system, including roads, traffic means, etc.;

- Tourist services, e.g. accommodation, host services, other tourist services, etc.;

- Product packages;

- All kinds of activities that can be enjoyed by tourists during their stay; public-utility services, e.g. banks, telecommunication, hospitals, etc..

Summarizing the aspects regarding the nature of destination and its determining factors (Angelo Presenza Lorn Sheehan - J.R. Brent Ritchie, 2005), the characteristics of destination can be listed as follows:

Destination:

- Area target chosen by the tourist as the target of his travel

- Receiving area that provides services for the tourist and people living on the spot

- It is defined from the point of view of the tourist

- A place/region that is confinable physically and geographically

- A place/region that contains tourist attractions, products, services and other background-services necessary for spending at least one day

- The tourist spends at least one night there

- It contains a lot of persons concerned who are cooperating with each other

- It has an image

- It has perception (it means that each of the tourists can form an opinion about a destination through their own "screen" subjectively)

- It provides integrated experience for the tourist

- In a wider sense, it is a tourist product that competes with other tourist products (destinations) on the market of tourism

- A kind of complex and integrated modern tourism controlling and management system necessary for a destination's successful operation

- It is a system built from below and supported from above

Not all locations, regions can become a tourist destination. There are certain basic criteria that have to be met so that a location, region can become a tourist destination. The above mentioned are only the most basic criteria. The determination and bordering of the destinations or the core area destinations suppose the development of a special system of criteria that is made according to preferences, expectations, points of view of the tourist first of all. 


\subsection{The connection between the system of destination and tourism}

The place of destination in the system of tourism is demonstrated by the system of tourism. Destination can be found on the side of supply (the product) from the two sub-systems of the tourism system. The tourist supplies consist of the factors of the receiving area that are used by the tourist during his stay. The central element of the supply is the tourist product that contains the services meeting the demands of the tourist.

Tourism is an integrated, open, complex system operating dynamically, each element of which (its micro- and macro environment) is interdependent. (Figure 1. "The system of tourism")

\begin{tabular}{|c|c|c|}
\hline Economics & & Society \\
\hline Demand & & Supply \\
\hline $\begin{array}{l}\text { The tourist } \\
\text { " motivation } \\
\text { " free time } \\
\text { " disposable income }\end{array}$ & Travel & $\begin{array}{l}\text { Tourist product } \\
\text { " attraction } \\
\text { " infrastructure } \\
\text { " service } \\
\text { " safety } \\
\text { " hospitability }\end{array}$ \\
\hline Market & $\begin{array}{l}\text { Marketing } \\
\text { DM organisation }\end{array}$ & Destination \\
\hline Culture & & Environment \\
\hline
\end{tabular}

1Figure 1: The system of the tourism

After Márton Lengyel: General theory of tourism, Budapest, 1992. edited by Anett Tözsér, 2007.

From the factors forming the two sub-systems of the tourism market, the supply (tourist product) consists of the following elements: attractions, accessibility, services, safety, hospitability, etc.. The elements of the tourist destination according to the above definition (Buhalis, 2000) run as follows: tourist attractions (natural and man-made, special events, etc.), accessibility, tourism services, product packages, activities, and public services. From the abovementioned, one can say that the elements and combination of the factors of supply and the ones forming the destination are the same. However, there is a difference because the tourist product can be only one product or some services or even a pile of services meeting the demands of the tourist being away from his home. From the tourist's point of view only the pile of complex services means a product because it has to meet all of his demands (Márton Lengyel, 1992). The product can be only one or several products as well, however destination can be characterised as a set of complex services and attractions related to each other.

Some scientists put an equal sign between the tourist product in a wider sense and the tourist destination: e.g. according to Bieger (1998) destination is just like a tourist product that competes with other products on the tourist market.

Destination management system being responsible for the tourist destination controlling and management forms a connection with the poles of demand and supply.

\subsection{The operation of destination management as the tourist value chain}

The simple value chain represents a process that delivers a product from the idea through the product development phase to the end user.

Michael Porter characterises the value chain with the connection of activities whose elements represent the different levels of providing offers. The principle of destination operation is similar to the one of the traditional value chain, too. However, destination management as the tourist value chain leads the tourist through the entire process of travel, right from the decision of travelling to the return. The traditional value chain puts the product and its development in the centre; the leading actor of the tourist value chain is the tourist who wants to use tourist products (tourist supply of destination) in a more complex way to be able to meet his demands.

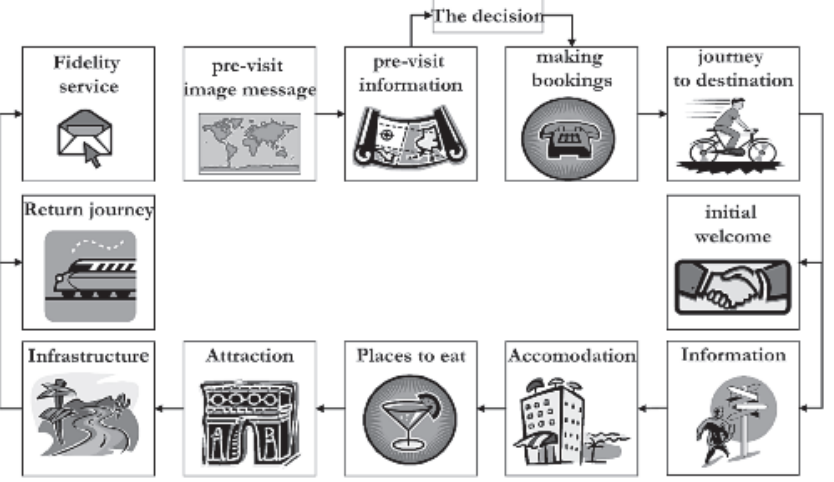

Figure 2: The tourist value chain

After „Using natural and cultural heritage for the development of sustainable tourism in non-traditional tourism destinations (2002); Key success factors: Designing a tourism offer", 28.p.; edited by Anett Tözsér, 2007.

The tourist value chain consist of the elements determining and influencing the travel process and of the elements provided by the specific destination.

There can be different actors behind the offering factors that form destination, just like e.g. the local self-government, the owners and operators of the attractions, services, local tourist consortiums and partnerships, civilian organisations, institutions supporting enterprises, tourism developing institutions, organisations, etc.. The effective operation of destination is taking the conscious cooperation of the characters for granted that is realized in the harmonized organization and operation of the products and services mostly.

It is important that service providers should provide the same high level of quality because a service of different levels of the key and supplementary functions of destinations can influence the judgement of the whole destination negatively.

For the operation of a destination as a tourist value chain an organisation is necessary that can establish a connection between the tourist and the receiving area, that is independent, has the suitable competences and means, and is capable to coordinate the characters and to build up the activities. 


\subsection{Characteristics of the tourist destination management}

On the basis of some definitions, we can sum up the point of the tourist destination management organisation in the following way:

- The tourist destination management organisation (Buhalis, 2000) takes the entire responsibility for the tourist products of the whole destination, for their development through controlling, encouraging and other means and for the development of a partnership that is able to provide positive experience for the tourists;

- Its main role, function is the establishment of the cooperation and coordination between the non-profit and private characters of tourism. Its purpose (Dr. Hilda Faragó, 2006) is to increase the tourism, the tourist income of the specific area and to strengthen the image of the territory. It usually introduces the tourist supplies of a specific area for the tourists and the branch of tourism in a way free of competition.

Table 1: Tourism destination management and its organisational characteristics

\begin{tabular}{|l|l|}
\hline VIEWPOINT & $\begin{array}{l}\text { CHARACTERISTICS OF DESTINATION } \\
\text { MANAGEMENT }\end{array}$ \\
\hline Character: & $\begin{array}{l}\text { - Directing } \\
\text { - Management } \\
\text { - Coordinating activity }\end{array}$ \\
\hline Mission: & $\begin{array}{l}\text { - To establish the sustainable and competitive } \\
\text { tourism in a specific area through the } \\
\text { comprehensive creation and operation of the }\end{array}$ \\
\hline Purposes: & $\begin{array}{l}\text { system of tourism } \\
\text { - To meet the demands of the tourists } \\
\text { - To ensure the profitability of the branch }\end{array}$ \\
\hline Financing: & $\begin{array}{l}\text { To get the local community take part in the } \\
\text { of life }\end{array}$ \\
\hline - To protect and take care of the environment \\
The organisation:
\end{tabular}

After Márton Lengyel: Regional (destination) tourism management. Proposal for Hungarian Tourism Committee, 2005. edited by Anett Tözsér, 2007.
According to the tourist destination management model (Márton Lengyel, 2005) the tourism destination management and its organisational characteristics can be described with the following points of view:

\subsection{Conclusions}

On the whole, tourist destination management (Márton Lengyel, 2005) means an activity that keeps an eye on the interests both of the tourists and the receiving communities and serving them as well. Its mission is: to provide adventures for the tourists, economic, social and environmental advantages for the receiving communities. Tourist destination management has to be carried out by an independent organisation with the suitable competence, means and experts to be able to perform its involved tasks.

\section{References}

Angelo Presenza - Lorn Sheehan - J.R. Brent Ritchie (2005): Towards a model of the roles and activities of destination management organizations.

http://www.atlas-

euro.org/pages/pdf/WUbarcelona/WU\%20txt\%20Juvan-

Presenza\%20et\%20al model\%20of\%20roles\%20and\%20activities \%20of\%20DMO.pdf

Don Fuller - Janet Hankan - Simon - Wilde (2005): Destination decision making and consumer demand: identifying critical factors. Centre for Enterprise Development and Reseearch, Occassional Paper, No.3.

Hilda Faragó (2006): Destination marketing. Tourism destination management course, Gyenesdiás.

László Puczkó - Dr. Tamara Rátz (1998): The effects of tourism, Aula - Kodolányi János College

Márton Lengyel (1992): General theory of tourism, KIT., Budapest

Márton Lengyel (2005): Regional (destination) tourism management. Proposal for Hungarian Tourism Committee, Budapest

Márton Lengyel (2006): Substance of tourism destination management. Tourism destination management course, Gyenesdiás

Larry Dwyer - Chulwon Kim: Destination competitiveness (2003): Determinants and indicators. Current Issues in Tourism, Volume 6., Issue 5 2003., pp. 369-414.

Roger Carter - Mike Fabricius (2006): Destination management for tourism - Introduction to destination management. Regional seminar/workshop for Africa: Tourism destination management routes to succes, Addid Ababa, Ethiopia

http://www.world-tourism.org/destination/eng.html

Dr. Roger Carter - Dr. Mike Fabricius: Destination management an overview, UNWTO Conference, „Creating competitive advantage for your destination”, Bp., 7February 2007.

http://www.destinationmanagement2007budapest.com/pres/0207/200 70207 3.pdf

Using natural and cultural heritage for the development of sustainable tourism in non-traditional tourism destinations. Key success factors (2002): Designing a tourism offer, European Commission, Tourism Studies and Publications

http://ec.europa.eu/enterprise/tourism/docs/studies/using natural cult ural heritage/ecosystems en/successfactors en.pdf 